\title{
Liposomal N-acetylcysteine Modulates the Pathogenesis of P. aeruginosa Isolated from the Lungs of Cystic Fibrosis Patient
}

Ahad Hasanin and Abdelwahab Omri*

The Novel Drug \& Vaccine Delivery Systems Facility, Department of Chemistry and Biochemistry, Laurentian University, Sudbury, ON, P3E 2C6, Canada

\begin{abstract}
$\mathrm{N}$-acetylcysteine (NAC) is a mucolytic agent with antimicrobial potential. We evaluated the antimicrobial activity of the free and liposomal NAC (F-NAC; L-NAC) against Pseudomonas aeruginosa. The minimum inhibitory concentrations (MIC), the minimum bactericidal concentrations (MBC) and the in vitro time kill studies of L-NAC were determined by broth-dilution method. Efficacy of the formulations on the production of $\mathrm{N}$-acyl homoserine lactone molecules, virulence factors and motility were determined. Eradication of bacterial community within biofilms was assessed using the Calgary Biofilm Device. The L-NAC Cytotoxicity and anti-bacterial adhesion potential to human lung cells were examined using pulmonary A549 cell lines. The MIC of L-NAC was lower than the free drug $(1250 \mathrm{mg} / \mathrm{L}$ and $5000 \mathrm{mg} / \mathrm{L}$, respectively). MBC for L-NAC was $2500 \mathrm{mg} / \mathrm{L}$ compared to $5000 \mathrm{mg} / \mathrm{L}$ for F-NAC. L-NAC at $2500 \mathrm{mg} / \mathrm{L}$ killed bacteria in $2 \mathrm{~h}$, whereas F-NAC exhibited the same effect at $5000 \mathrm{mg} / \mathrm{L}$. Quorum sensing was significantly inhibited by L-NAC $(P<0.001)$. At 1/8 MIC, L-NAC reduced the production of bacterial proteases significantly more than that of F-NAC at 1/4 MIC. L-NAC was also able to reduce the bacterial motility at eightfold lower concentration than F-NAC $(P<0.001)$. As for biofilms, L-NAC provided $75 \%$ protection against biofilm formation, $90 \%$ reduction in the formed biofilms, and a $46 \%$ eradication effect on bacterial community within biofilms compared to treated biofilm with PBS $(P<0.001)$. Finally, L-NAC at $2500 \mathrm{mg} / \mathrm{L}$ was safe to A549 cells, reduced bacterial adhesion by $15 \%$ compared to control $(P<0.001)$. These data indicate that L-NAC formulation is more effective than F-NAC against $P$. aeruginosa and has the potential to improve therapeutic outcomes in CF patient.
\end{abstract}

Keywords: Biofilm; Quorum sensing; Motility; Virulence factors; Bacterial adhesion

\section{Introduction}

Cystic fibrosis $(\mathrm{CF})$ is a genetic disease without any existing treatment [1]. It is the most common disorder among the Caucasians population which is caused by mutations of the $\mathrm{CF}$ transmembrane conductance regulator gene (CFTR) located on chromosome 7 [2]. There are more than 1900 identified CFTR mutations [3], the most prevalent mutation is caused by deletion of phenylalanine at position 508, known as $\Delta$ F508 [4]. CFTR mutations affect ion and water transport channel in epithelial cells [5] in many organs including pancreas, small intestine, liver, reproductive tract, sweat glands and respiratory tract [6]. Even though $\mathrm{CF}$ is known to be a multiorgan disease, pulmonary infections have the greatest role in morbidity and mortality [7] leading to death in $90 \%$ of CF patients [8]. The diminishment of chloride and water channels leads to viscous secretions and impairs mucociliary clearance [9] which allows the bacteria to multiply in the mucus and use it as an energy source [10]. Staphylococcus aureus, Haemophilus influenzae and Pseudomonas aeruginosa are the most commonly occurring bacteria in $\mathrm{CF}$, where they contribute to inflammation early stages [11]. It is evident from previous studies that $P$. aeruginosa is the most predominant pathogen [12] which colonizes the lungs of $80 \%$ of adults with CF [13].

P. aeruginosa is a Gram-negative bacterium which is considered as a major opportunistic pathogen that causes infectious diseases, and is the leading cause of chronic pulmonary infections in CF. It chronically colonizes in the lungs of CF patients and causes progressive lung damages, respiratory failure and death [14]. P. aeruginosa depends on chemical signaling molecules to organize important activities for their survival [15]. These chemicals are known as quorum sensing (QS), which are released by the bacteria in response to an increase of bacterial cell density [16]. The most distinguished type among these signal molecules are $N$-acyl homoserine lactones (AHLs) These chemicals bind to their promoters to stimulate the formation of biofilms and virulence factors
(VF) [17]. P. aeruginosa pathogenesis is closely associated with its motility such as swimming, swarming and twitching, which allows it to attach to different surfaces forming a biofilm [18].

P. aeruginosa grows into biofilms as a survival strategy. These biofilms are described as communities of microbial cells which are enclosed in polysaccharides matrix, proteins and nucleic acids [19]. P. aeruginosa forms three dimensional mushroom shaped colonies attached to the surface with the help of flagellar motility and type IV pili-mediated twitching motility [20]. Biofilms work as a shield to protect bacterial cells against the host immune system and antibiotics [21-24]. The minimum inhibitory concentration (MIC) and minimum bactericidal concentration (MBC) of antibiotics are found to be 100 to 1000 fold higher for mature biofilms when compared to planktonic cells or young biofilms [25]. These communities are predominantly associated with persistence of infection as well as resistant to antibiotic; thereby making the biofilms of $P$. aeruginosa hard to control and eradicate [26].

P. aeruginosa releases several VF such as elastase, chitinase, lipase and protease [27-29]. These VF have a major effect on the alveolar epithelial permeability by damaging collagen, $\alpha$-1-antitrypsin, elastin, immunoglobulins and cytokines and lead to more mucin secretion from goblet cells $[29,30]$.

*Corresponding author: Abdelwahab Omri, The Novel Drug \& Vaccine Delivery Systems Facility, Department of Chemistry and Biochemistry, Laurentian University, Sudbury, ON, P3E 2C6, Canada, Tel: +1-705-675-1151, ext. 2190; Fax: +1-705675-4844; E-mail: aomri@laurentian.ca

Received July 25, 2014; Accepted August 21, 2014; Published August 27, 2014

Citation: Hasanin A, Omri A (2014) Liposomal N-acetylcysteine Modulates the Pathogenesis of $P$. aeruginosa Isolated from the Lungs of Cystic Fibrosis Patient. $J$ Nanomed Nanotechnol 5: 219. doi: 10.4172/2157-7439.1000219

Copyright: (c) 2014 Hasanin A, et al. This is an open-access article distributed under the terms of the Creative Commons Attribution License, which permits unrestricted use, distribution, and reproduction in any medium, provided the original author and source are credited. 
Aggressive antibiotic therapy regimens are prescribed for $\mathrm{CF}$ patients from an early age to reduce bacterial infection [31] and delay an eventual chronic lung infection [8,32]. However; this strategy increases antibiotic resistance [33] which is a sign of antibiotic therapy failure [25]. It is well established that once the organism has launched a chronic infection in the bronchial tree, it cannot be eradicated [31]. Not only the bacterial load is problematic in CF, but also abnormalities in mucous secretion also have a great impact on the CF patients' health [34]. Studies have shown that abnormal mucous secretions in $\mathrm{CF}$ patients as well as P. aeruginosa biofilms formation are advantageous for bacterial survival in the host system because they limit antimicrobial penetration $[26,35,36]$. Mucolytic agent such as $\mathrm{N}$-acetylcysteine (NAC) is one of the best parts of the treatment regime not only due to its mucolytic effect, but also to its ability to reduce biofilm formation [37].

NAC is L-cysteine derivative that has been known for its ability to break disulfide bonds present in mucin and to decrease the mucous viscosity as well as elasticity [38-41]. Several studies have reported the potential of NAC as an antimicrobial agent for a variety of bacteria including Staphylococcus epidermidis, Streptococcus pneumoniae, Enterococcus faecalis, Escherichia coli and P. aeruginosa [42-47]. The antimicrobial activities of NAC are believed to be due to its ability to inhibit cysteine utilization in bacteria or due to the reaction between bacterial cell proteins and NAC sulfhydryl group [23,43]. Previous studies have also reported the capability of NAC to disrupt biofilms, reduce adhesion of bacteria onto surfaces and cause a reduction of lipopolysaccharide induced lung inflammation [44,47]. However, other studies have also demonstrated that the half-life of NAC is short, approximately $2.15 \mathrm{~h}$ [48], and because of its high molecular weight is not able to cross cell membrane barriers [49,50]. Therefore, there is a necessity for encapsulation of NAC into a delivery system such as liposome to prolong its effects, enhance its efficacy and improve the uptake of NAC through fusion with bacterial membrane [51,52].

Liposomes are spherical nontoxic vehicles with sizes ranging from nanometers to micrometers, consisting of one or more lipid bilayers [52]. Typically they are produced from phospholipids; thereby liposomes are biocompatible and biodegradable. Liposomes are preferred for the delivery of therapeutic agents because they provide a sustained release of the drugs and reduce their toxic effects, as well as increase the bioavailability of insoluble hydrophobic drugs $[53,54]$.

Herein, we investigated the effects of L-NAC against growth of $P$. aeruginosa; on attenuation of quorum sensing; on virulence factors such as chitinase, elastase, lipase and protease enzymes; on motility of $P$. aeruginosa; on formation of biofilms; and on P. aeruginosa adhesion to lung cells.

\section{Materials and Methods}

\section{Chemicals}

Dipalmitoylphosphatidylcholine (DPPC) was obtained from Avanti Polar Lipids, Inc. (Alabaster, Alabama, USA). N-Acetylcysteine (NAC), Triton X-100, Trypan Blue, Chitin azure, elastin-Congo Red and all other chemicals were purchased from Sigma-Aldrich Co. (Oakville, ON, Canada). Mueller Hinton Agar (MHA), Trypsin EDTA, penicillin/streptomycin, Dulbecco's modified Eagle's medium (DMEM) and Dulbecco's phosphate buffered saline (DPBS), Cell Titer-Blue Cell viability assay kit and Chloroform were purchased from Fisher Scientific (Ottawa, ON, Canada). Lysogeny broth and Luria Bertani (LB) agar were from (Becton Dickinson Microbiology Systems, Oakville, ON,
Canada). Cationic Mueller Hinton broth (CMHB) and Crystal violet (CV) were purchased from BD (Mississauga, ON, Canada).

\section{Microorganisms}

The mucoid and non-mucoid clinical isolates of $P$. aeruginosa (PA13572, PA-5, PA-M13641-2, PA-7, PA-13639-2, PA-3, PA-M13640, PA11, PA-12, PA-M13639-1, PA-48913, PA-M26250, PA-1, PA-48912-2, PA-48912-1, PA-8 and PA-13641-1) were isolated from the sputum of CF patients and obtained from Clinical Microbiology Laboratory of Sudbury Regional Hospital (Sudbury, ON, Canada). The American Type Culture Collection of P. aeruginosa (ATCC 25619, ATCC 27853 and ATCC 10145) strains were purchased from PML Microbiologicals (Mississauga, ON, Canada). Pseudomonas aeruginosa strain (PAO1) was generously donated by Dr. R.E.W. Hancock (University of British Columbia). Bacteria were preserved at $-80^{\circ} \mathrm{C}$ in Mueller-Hinton broth containing glycerol at a final concentration of $10 \%(\mathrm{v} / \mathrm{v})$. Agrobacterium tumefaciens strain A136 (pCF218) (pCF372) (Ti-) was used as the biosensor for the detection of AHLs and cultured in Lysogeny broth at $30^{\circ} \mathrm{C}$.

\section{Cell culture}

A549 human lung carcinoma epithelial cells were obtained from the American Type Culture Collection (ATCC CCL-185, Manassas, USA) and cultured in DMEM supplemented with $10 \%$ fetal bovine serum (FBS) and $1 \%$ penicillin/streptomycin. The cells were grown to $85 \%$ confluence in $5 \% \mathrm{CO}_{2}$ at $37^{\circ} \mathrm{C}$ and maintained using traditional cell culture techniques. For viability and adhesion studies cells were treated with non-supplemented DMEM media to assure accuracy of results.

\section{Preparation of L-NAC}

NAC was incorporated into liposomes containing a mixture of DPPC and NAC in a 1:1 molar ratio and prepared by the dehydrationrehydration method as described previously [55]. DPPC were dissolved in chloroform in a $50 \mathrm{~mL}$ round-bottomed flask and dried at $45^{\circ} \mathrm{C}$ with a rotary evaporator (BuchiRotavapor R 205). The lipid film was then hydrated with $1 \mathrm{~mL}$ of $10 \mathrm{mg} / \mathrm{mL}$ NAC stock solution and subsequently sonicated (model 500 Dismembrator, Fisher Scientific) for $5 \mathrm{~min}$ (cycles of 40s on and 20s off). Once multilamellar vesicles were formed, the liposome mixture was freeze-dried overnight as reported previously [56] and un encapsulated drug was separated by centrifugation at $28000 \times$ g (Thermo IEC, IEC multi-RF, Thermo Fisher Scientific, Canada). After rehydration of liposomes, liposomal vesicle size and the polydispersity index (PI) were determined with Submicron Particle Sizer (Nicomp Model 270, Santa Barbara, CA). The liposomal size was found to have mean diameter $200 \mathrm{~nm}$. The PI of the liposomes was 0.85 \pm 0.04 . The encapsulation efficiency of NAC in DPPC-liposomes was $37 \pm 1.5 \%$ after rehydration of liposomes. The encapsulation efficiency (E.E.) was calculated as follows:

\section{E. E. $=($ Released NAC Conc. / Initial NAC Conc. $) \times 100$}

The liposomes were shown to release $20 \%$ and $25 \%$ of its content in NAC after $24 \mathrm{~h}$ incubation in PBS $\left(4^{\circ} \mathrm{C}\right)$ and $37^{\circ} \mathrm{C}$ respectively. When incubated at $37^{\circ} \mathrm{C}$ in rat bronchoalveolar lavage an plasma, the liposomes, release respectively $30 \%$ and $40 \%$ of its content in NAC.

The NAC concentration was detected by spectrophotometry and the absorbance was measured at $412 \mathrm{~nm}$

\section{Antimicrobial activity of free and liposomal NAC}

To test the antimicrobial activity of liposomal NAC on $P$. aeruginosa the MICs and MBCs were evaluated. The MICs and MBCs of all 21 
strains of $P$. aeruginosa used in this study were determined by using the micro-broth dilution technique. Serial dilutions of F-NAC and L-NAC at $(10000,5000,2500,1250,630,310,160,80$ and $40 \mathrm{mg} / \mathrm{L})$ were prepared. In addition, bacteria were exposed to empty liposomes as well as NAC to test the effect of empty liposomes and NAC without encapsulation. Overnight cultures of bacteria suspensions in cationic Mueller Hinton broth (CMHB) were then added to reach a final concentration of 0.5 McFarland standards to each F-NAC and L-NAC concentrations [57,58]. Samples containing bacterial culture without the drug were included as positive controls. P. aeruginosa strains (PAO1, ATCC 25619, ATCC 27853, ATCC 10145PA-13572, PA-5, PA-M136412, PA-7, PA-13639-2, PA-3, PA-M13640, PA-11, PA-12, PA-M13639-1, PA-48913, PA-M26250, PA-1, PA-48912-2, PA-48912-1, PA-8 and PA13641-1) were used. The MIC of F-NAC and L-NAC that prevented bacterial growth in the cultures were inspected after incubation at $37^{\circ} \mathrm{C}$ for $24 \mathrm{~h}$ and the MICs were recorded. The lowest concentrations of either F-NAC or L-NAC that resulted in more than $99.9 \%$ reduction in bacterial growth were recorded as MBCs [52]. All samples were prepared in triplicates and three separate experiments were performed.

\section{Growth of PA-13572 in the presence of L-NAC at sub-MIC}

The effect of F-NAC and L-NAC on the bacterial growth at subinhibitory concentrations was evaluated on clinically isolated $P$. aeruginosa strain (PA-13572) from CF patients. The clinically isolated PA-13572 growth was monitored for $24 \mathrm{~h}$. A final concentration of $1.5 \times 10^{8}$ colony forming units $(\mathrm{CFU}) / \mathrm{mL}$ was mixed with $\mathrm{F}-\mathrm{NAC}$ and L-NAC at sub-MICs $(1 / 2$ and $1 / 4)$ and incubated at $37^{\circ} \mathrm{C}$ with rapid shaking. At time 1, 2, 3, 4, 6, 8, 12 and $24 \mathrm{~h}$, turbidity was measured at $\mathrm{OD}_{600}$ [59]. The experiment was repeated three times in triplicates.

\section{Time kill study}

Time kill study was conducted to evaluate the microbial reduction by liposomal NAC compared to free NAC in regard to time length. In time kill experiments clinical isolate of $P$. aeruginosa (PA-13572) in a final concentration between 6 and $8 \log _{10} \mathrm{CFU} / \mathrm{mL}$ was cultured in test tubes containing CMHB with either F-NAC or L-NAC at final concentration of 5000,2500 and $1250 \mathrm{mg} / \mathrm{L}$ or with no drug as a control. These cultures were then incubated in a shaker incubator at $37^{\circ} \mathrm{C}$ for 2 , 4,6 and $24 \mathrm{~h}$. At the end of each time period, tenfold serial dilutions were prepared with PBS ( $\mathrm{pH}=7.4)$ and $100 \mu \mathrm{L}$ samples were plated onto Mueller Hinton agar (MHA) plates in triplicate. The CFU at each time period were then counted after $18 \mathrm{~h}$ incubation at $37^{\circ} \mathrm{C}$. Plates with 30-300 colonies were used for CFU counts as reported by Rukholm et al. [52]. Three separate experiments were performed in triplicate.

\section{QS molecules production and $\beta$-galactosidase activities}

We examined weather L-NAC or free NAC have quorum sensing inhibitory (QSI) effect, therefore, PA-13572 was grown overnight and $\left(\mathrm{OD}_{600}=0.13\right)$ bacterial solution was prepared in a $100 \mathrm{~mL}$ flasks. When the bacterial cell density doubled to an $\mathrm{OD}_{600}=0.26$, subinhibitory concentrations of F-NAC and L-NAC were added to the bacterial suspension (1/16-1/4 the MICs). Theseflasks were then incubated at $37^{\circ} \mathrm{C}$ in shaker incubator rotating for $24 \mathrm{~h}$. After $24 \mathrm{~h}$, bacterial-NAC mixtures were centrifuged at $16,000 \times \mathrm{g}$ for $20 \mathrm{~min}$ at $4^{\circ} \mathrm{C}$ and the supernatants were then filter sterilized $(0.22 \mu \mathrm{M})$ as reported previously [60]. LB agar was prepared and cooled to $45^{\circ} \mathrm{C}$, and $\beta$-D-galactopyranoside $(20 \mathrm{mg} /$ $\mathrm{mL}$ in dimethylformaldehyde) with Agrobacterium tumefaciens strain A136 cells equal to a density of $10^{6} \mathrm{CFU} / \mathrm{mL}$ was added to the agar. This mixture was poured into Petri dishes, holes were punctured in the agar using a vacuumed device and $80 \mu \mathrm{l}$ from treated bacteria and control supernatants were added to the holes. The plates were then incubated for $48 \mathrm{~h}$ at $30^{\circ} \mathrm{C}$. AHL production was detected as blue-green pigment and documented by a digital camera. To quantify the level of AHLs in the bacterial supernatant, the ability of $P$. aeruginosa AHL signaling molecules to activate the release of $\beta$-galactosidase in A. tumefaciens (A136) was examined in this experiment as reported previously [61]. This bioassay was carried out starting with tubes containing $4 \mathrm{~mL}$ of A136 and $1 \mathrm{~mL}$ of supernatant incubated in a $30^{\circ} \mathrm{C}$ water bath for $5 \mathrm{~h}$ with rotation at $100 \mathrm{rpm}$. After incubation, the bacterial cell densities were read at $\mathrm{OD}_{600}$ and then centrifuged at $16,000 \times \mathrm{g}$ for $15 \mathrm{~min}$ at $4^{\circ} \mathrm{C}$. Supernatants were discarded and pellets were resuspended in 4 $\mathrm{mL}$ of $\mathrm{Z}$ buffer $\left(0.06 \mathrm{M} \mathrm{Na}_{2} \mathrm{HPO}_{4} .7 \mathrm{H}_{2} \mathrm{O}, 0.04 \mathrm{M} \mathrm{NaH}_{2} \mathrm{PO}_{4} \cdot \mathrm{H}_{2} \mathrm{O}, 0.01\right.$ $\mathrm{M} \mathrm{KCl}, 0.001 \mathrm{M} \mathrm{MgSO}_{4} .7 \mathrm{H}_{2} \mathrm{O}, 0.05 \mathrm{M} \beta$-mercaptoethanol, $\mathrm{pH} 7.0$ ). These cells were then permeabilized by adding a solution of $200 \mu \mathrm{l}$ of chloroform and $100 \mu \mathrm{l}$ of $0.1 \%$ sodium dodecyl sulphate. Then, $0.4 \mathrm{~mL}$ of $O$-nitrophenol- $\beta$-D-galactopyranoside ( $4 \mathrm{mg} / \mathrm{mL}$ in PBS) was added to the samples prior incubation. Samples were then incubated again until the development of yellow color and the time was recorded. To stop the reaction, $1 \mathrm{~mL}$ of $1 \mathrm{M} \mathrm{Na}_{2} \mathrm{CO}_{3}$ was added. Optical density of the reaction samples were measured at 420 and $550 \mathrm{~nm}$. Miller units of $\beta$-galactosidase were calculated as $\left[\left(1000 \times A_{420 \mathrm{~nm}}\right)-\left(1.75 \times A_{550 \mathrm{~nm}}\right)\right] /$ (time $\times$ volume $\times A_{600 m m}$ ) as described previously [62].

\section{Production of PA-13572 virulence factors in the presence of L-NAC}

To determine the effect of L-NAC on virulence factors, PA-13572 filtered supernatant was prepared as mentioned previously in the QS assay. For the chitinase assay, $1 \mathrm{~mL}$ of the filtered supernatant was mixed with $1 \mathrm{~mL}$ PBS and $5 \mathrm{mg}$ of insoluble chitin azure and incubated at $37^{\circ} \mathrm{C}$ for $24 \mathrm{~h}$ with $200 \mathrm{rpm}$ agitation. The samples were then centrifuged at $16,000 \times \mathrm{g}$ for $10 \mathrm{~min}$ at $4^{\circ} \mathrm{C}$ in order to remove the insoluble chitin azure, absorbance was measured at $\mathrm{OD}_{290}$. For the elastase assay, the filtered supernatant $(1 \mathrm{~mL})$ was mixed with $1 \mathrm{~mL}$ PBS and $20 \mathrm{mg}$ of the insoluble elastin-congo red, and incubated with $200 \mathrm{rpm}$ agitation for $24 \mathrm{~h}$ at $37^{\circ} \mathrm{C}$. The absorbance was measured at $\mathrm{OD}_{495}$ after the insoluble elastin-congo red was removed by centrifugation at $16,000 \times \mathrm{g}$ for 10 $\min$ at $4^{\circ} \mathrm{C}$ [29]. For lipase assay, $0.6 \mathrm{~mL}$ of the filtered supernatant was mixed with $0.6 \mathrm{~mL} 10 \%$ Tween 20 in Tris-buffer saline, $2 \mathrm{~mL} \mathrm{H}_{2} \mathrm{O}$ and $0.1 \mathrm{~mL}$ of $1 \mathrm{~mol} / \mathrm{L} \mathrm{CaCl}_{2}$ and incubated with $200 \mathrm{rpm}$ agitation at $37^{\circ} \mathrm{C}$ for $24 \mathrm{~h}$. Turbidity of the samples were then measured at $\mathrm{OD}_{400}$ [59]. These experiments were repeated three times in triplicate and data was normalized by dividing the optical density by the cell density $\left(\mathrm{OD}_{600}\right)$. For the protease assay, Petri dishes were prepared with $2 \%$ agar containing $3 \%$ skimmed milk, $100 \mu \mathrm{l}$ of the filtered supernatants were added to the well of the dishes and incubated at $37^{\circ} \mathrm{C}$ for $48 \mathrm{~h}$. The clear zones were then measured [29]. The experiment was repeated three times in triplicates.

\section{Effects of L-NAC on PA-13572 motility}

The effect of L-NAC on PA-13572 motility was examined in the presence and absence of the sub-inhibitory concentrations of both F-NAC and L-NAC. Mueller-Hinton broth was prepared with $1.0 \%$ agar for twitching, $0.5 \%$ agar for swarming and $0.3 \%$ for swimming motility. For the twitching experiment, $1 \mathrm{~mL}$ of the bacteria $\mathrm{OD}_{600}=0.13$ was stabbed into the agar-plastic interface, point inoculated on the surface for the swarming examination and stabbed into the center of agar for the swimming motility. Petri dishes were then incubated at $37^{\circ} \mathrm{C}$ for $12 \mathrm{~h}$ for swarming and swimming and diameters were measured. Twitching samples were incubated for $24 \mathrm{~h}$, agar removed 
and Petri dish was stained with $1 \% \mathrm{CV}$ after it was air dried and pattern was measured $[29,59,63]$. These experiments were repeated three times in triplicate.

\section{Antibiofilms activities}

Biofilms experiments were assessed to determine whether the presence of L-NAC at sub-MICs (1/2-1/64 the MIC) could prevent the formation of biofilms on surfaces, while the biofilm reduction experiments allowed determination of whether L-NAC at sub-MICs (1/2-1/32 the MIC), MIC and $2 \times$ MIC could reduce young structured biofilms. Using a surface binding assay, biofilm formation was assessed in 96-well plates with F-NAC, L-NAC or without treatment as control. For the prevention experiment, PA-13572 (1:100 dilution of the 0.5 McFarland standards) were grown in the presence of F-NAC and L-NAC at sub-MICs for $18 \mathrm{~h}$ at $37^{\circ} \mathrm{C}$ and unadhered bacteria were washed off with PBS. Attached bacteria were stained with $1 \% \mathrm{CV}$, dissolved with $95 \%$ ethanol and the absorbance was read at $\mathrm{OD}_{590}$ using a spectrophotometer. The experiment was repeated three times in triplicate. For biofilm reduction, bacterial biofilms were allowed to structure on the surface for $18 \mathrm{~h}$, unadhered bacteria were removed and structured biofilms were then incubated for an additional $18 \mathrm{~h}$ with F-NAC and L-NAC before measuring biofilm formation [29]. Effect of L-NAC on $P$. aeruginosa within mature biofilms was also tested as described previously [59]. Calgary Biofilm Device plates (CBD; MBEC Biofilms Technology Ltd., Calgary, Alta., Canada) were used for growing mature biofilms in this experiment. $24 \mathrm{~mL}$ of the PA-13572 strain $\left(1.5 \times 10^{6} \mathrm{CFU} / \mathrm{mL}\right)$ was added to the Calgary biofilm device plates. This plate was then incubated in an incubator shaker rotating at $50 \mathrm{rpm}$ at $37^{\circ} \mathrm{C}$ for $96 \mathrm{~h}$ to ensure equal distribution of medium in the troughs and adherence of bacteria to the pegs. Medium was replaced with fresh broth every $24 \mathrm{~h}$ to remove unattached bacteria. On the fifth day, biofilms formed on the pegs were rinsed with medium two times. For positive control, 3 pegs were removed with a sterile forceps and placed into a microcentrifuge tubes containing $1 \mathrm{~mL}$ PBS, which was then sonicated to detach bacterial biofilms from pegs into the PBS. The solution was then serially diluted (tenfold) and $100 \mu \mathrm{l}$ of each dilution was plated on MHA plates and incubated for $24 \mathrm{~h}$ at $37^{\circ} \mathrm{C}$ for $\mathrm{CFU}$ counts. The remaining pegs were then submerged into a 96 -well plate containing $200 \mu \mathrm{l}$ of 10 -fold dilutions of F-NAC and L-NAC. The plate was incubated for another $24 \mathrm{~h}$ at $37^{\circ} \mathrm{C}$, peg lids were washed, pegs were removed and transferred to microcentrifuge as mentioned above, and $\mathrm{CFU}$ were counted after incubation for $24 \mathrm{~h}$ at $37^{\circ} \mathrm{C}$. This experiment was repeated three times in triplicates.

\section{Toxicity of L-NAC}

Using traditional cell culture techniques, human lung carcinoma epithelial cell line A549 were grown to $85 \%$ confluence in $5 \% \mathrm{CO}_{2}$ at $37^{\circ} \mathrm{C}$ and maintained in DMEM supplemented with $10 \% \mathrm{FBS}$ and $1 \%$ penicillin/streptomycin. At confluence, cells were seeded into 24 -well plates at a density of $2 \times 10^{4}$ cells/well and allowed to adhere overnight. On the next day, media was discarded and cells were washed with PBS to remove any traces of FBS and antibiotic. F-NAC and L-NAC were prepared in non-supplemented media at a serial dilution of 2500 , $1250,630,310,160,80$ and $40 \mathrm{mg} / \mathrm{L}$, and added to the adhered cells. Untreated cells (non-supplemented media, no NAC added) were used as control. Plates were then incubated at $37^{\circ} \mathrm{C}$ in $5 \% \mathrm{CO}_{2}$ for $24 \mathrm{~h}$. The wells were then washed twice with DMEM and exposed to a mixture of $500 \mu \mathrm{l}$ of media and $100 \mu \mathrm{l}$ of resazurin. Cells were then incubated in the dark overnight at $37^{\circ} \mathrm{C}$ in $5 \% \mathrm{CO}_{2}$. Solution were then transferred to cuvettes, absorbance was read at $570 \mathrm{~nm}$ using $600 \mathrm{~nm}$ as a reference wavelength. For the blank, a mixture of $500 \mu \mathrm{l}$ media and $100 \mu \mathrm{l}$ cell titer blue dye was used [64]. This experiment was repeated three times in triplicates.

\section{In vitro effects of L-NAC on bacterial adhesion to human lung cells}

The effects of L-NAC on PA-13572 adhesion to A549 cells were studied using two different procedures

Treatment of bacteria with F-NAC and L-NAC prior incubation with A549: In this experiment bacteria were exposed to F-NAC or L-NAC prior to incubation with A549 cells as described previously [64]. Briefly, A549 cells were grown to $85 \%$ confluence in $5 \% \mathrm{CO}_{2}$ at $37^{\circ} \mathrm{C}$ and maintained in DMEM supplemented with $10 \%$ FBS and $1 \%$ penicillin/ streptomycin, cells were then washed twice with PBS and incubated with non-supplemented media for $2 \mathrm{~h}$ prior to addition of bacteria. Bacteria (PA-13572) were grown over night in a shaker incubator at $37^{\circ} \mathrm{C}$ and adjusted to $0.5 \mathrm{McF}$ arland standards in non-supplemented DMEM to avoid any interaction. Bacterial aliquots were incubated in a shaker incubator for $3 \mathrm{~h}$ at $37^{\circ} \mathrm{C}$ with F-NAC and L-NAC in final concentrations of $2500,1250,630,310$ and $160 \mathrm{mg} / \mathrm{L}$. Treated bacteria were added onto cell monolayers for $3 \mathrm{~h}$ at $37^{\circ} \mathrm{C}$ supplemented with $5 \% \mathrm{CO}_{2}$. Non treated cells were also incubated to be used as positive control. After incubation, cells were washed five times with PBS to remove any non-adhered bacteria. Using a sterilized cell lifter (Costar, Fisher Scientific) cells were removed and re-suspended in PBS, $100 \mu \mathrm{l}$ of each sample was plated on MHA plates in triplicates. Agar plates were then incubated for $24 \mathrm{~h}$ at $37^{\circ} \mathrm{C}$. Bacterial colonies were counted, to determine the number of adhered bacteria.

A549 treatment with F-NAC and L-NAC prior exposure to bacteria: In this experiment A549 cells were grown as mentioned previously, and then they were treated with F-NAC and L-NAC in final concentrations of $2500,1250,630,310$ and $160 \mathrm{mg} / \mathrm{L}$ for $3 \mathrm{~h}$ prior to bacterial exposure. After incubation cells were washed twice with non-supplemented media to remove any traces of drug. PA-13572 were grown over night in a shaker incubator at $37^{\circ} \mathrm{C}$ and adjusted to 0.5 McFarland standards in non-supplemented DMEM. Bacterial aliquots were added to the cells monolayers and incubated for another $3 \mathrm{~h}$ to allow bacteria to adhere. The same procedures were applied to evaluate bacterial adhesion to the lung cells. Both experiments were repeated three times in triplicate.

\section{Data analysis}

The data were represented as mean \pm S.E.M. of three separate experiments. All groups were compared by one-way ANOVA method using GraphPad Prism. Probability $(P)$ values of ${ }^{*} P<0.05,{ }^{* *} P<0.01$ and ${ }^{* * *} P<0.001$ were reported as statistically significant.

\section{Results}

\section{Antimicrobial activity of free and liposomal NAC}

The antimicrobial activity of liposomal NAC on $P$. aeruginosa was evaluated. MIC and MBC values of F-NAC and L-NAC against clinical isolates and laboratory strains of $P$. aeruginosa are shown in Table 1. The MIC values for L-NAC were significantly lower than similar concentrations of F-NAC for the clinically isolated strains of P. aeruginosa (PA-13572, PA-5, PA-M13641-2, PA-3, PA-11, PA-12, PA-48913, PA-M26250, PA-1 and PA-48912-2) which presented an MIC of $1250 \mathrm{mg} / \mathrm{L}$ for L-NAC verses $5000 \mathrm{mg} / \mathrm{L}$ for F-NAC. However, there were no differences in the MIC between F-NAC and L-NAC on P. aeruginosa strains (PAO1, ATTC 25619, ATTC 27853, ATTC 10145 


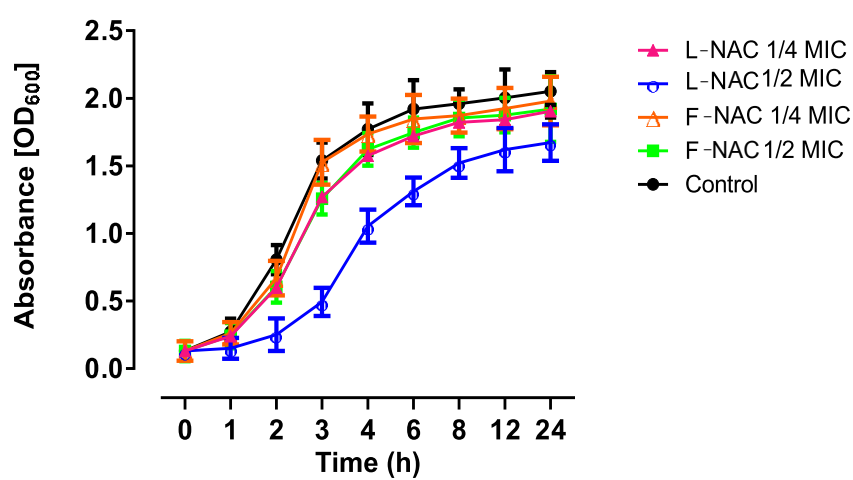

Figure 1: Growth curve of $P$. aeruginosa PA-13572. P. aeruginosa was exposed to media without antibiotics (filled circles), in the presence of sub-inhibitory concentrations of $1 / 2 \mathrm{MIC}$ of L-NAC [ $625 \mathrm{mg} / \mathrm{L}]$ (open circle), $1 / 4 \mathrm{MIC}$ of L-NAC [312.5 mg/L] (filled triangle), 1/2 MIC of F-NAC [ 2500 $\mathrm{mg} / \mathrm{L}]$ (filled squares), or $1 / 4 \mathrm{MIC}$ of F-NAC [ $1250 \mathrm{mg} / \mathrm{L}]$ (open triangle). The experiment was performed three times with means shown.

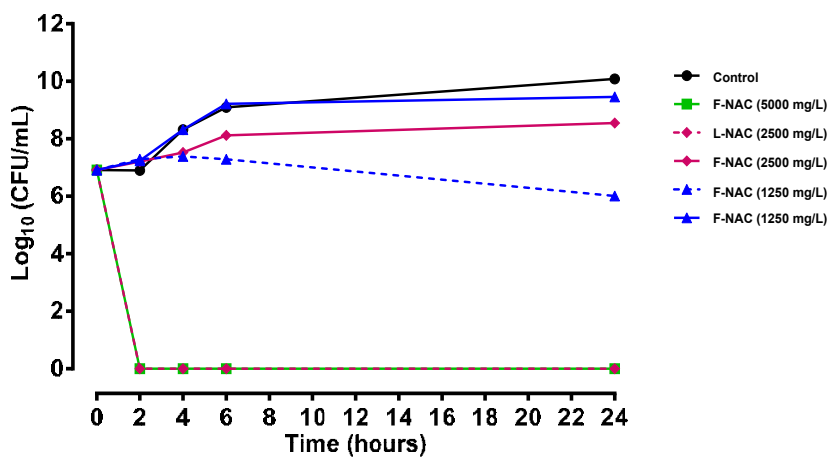

Figure 2: Time kill curves for PA-13572. P. aeruginosa exposed to 5000 , 2500 and $1250 \mathrm{mg} / \mathrm{L}$ of free NAC as well as 2500 and 1250 of liposomal NAC for time periods of 2, 4, 6 and $24 \mathrm{~h}$. After each time period samples were diluted and then cultured on Petri dishes, these dishes were incubated at $37^{\circ} \mathrm{C}$ for $18 \mathrm{~h}, \mathrm{CFU}$ were counted. The results represented the mean \pm S.E.M of three independent experiments in triplicates.

PA-7, PA-13639-2, PA-M13640, PA-M13639-1, PA-48912-1, PA-8 and PA-13641-1) where they all exhibited an MIC of $5000 \mathrm{mg} / \mathrm{L}$. The $\mathrm{MBC}$ values of F-NAC for all strains were either equal to or two times higher the MBC for L-NAC. The MIC values of DPPC and NAC were not different than F-NAC and empty liposomes had no antimicrobial activity.

\section{Growth of PA-13572 in the presence of L-NAC at sub-MIC}

The effect of F-NAC and L-NAC on the bacterial growth at subinhibitory concentrations was evaluated on several clinically isolated $P$. aeruginosa from CF (data not shown), then we chose one strain (PA-13572), which was affected mostly by NAC and had a significant different between the F-NAC and L-NAC to be used as a model of $P$. aeruginosa for the rest of the experiments. The growth curves for PA13572 grown in presence or absence of sub-MICs (1/4-1/2 the MICs) for both F-NAC and L-NAC were determined to concentrations that do not inhibit bacterial growth (Figure 1). Since the sub-MICs $1 / 4$ did not reduce the growth of bacteria compared to the control, all the experiments that involve QS, VF and bacterial motility were done using concentrations of 1/16-1/4 the MICs of F-NAC or L-NAC.

\section{Time kill study}

In this study a maximum of $24 \mathrm{~h}$ exposure of PA- 13572 to 5000 , 2500 and $1250 \mathrm{mg} / \mathrm{L}$ of F-NAC or L-NAC was studied. The results of the time kill curves for clinically isolated PA-13572 P. aeruginosa are shown in Figure 2. At $5000 \mathrm{mg} / \mathrm{L}$ of F-NAC was able to eradicate bacterial growth after $2 \mathrm{~h}$. However, at $2500 \mathrm{mg} / \mathrm{L}$ liposomal $\mathrm{N}$-acetylcysteine was completely able to eradicate bacteria at $2 \mathrm{~h}$, whereas free $\mathrm{N}$-acetylcysteine at $2500 \mathrm{mg} / \mathrm{L}$ did not affect the bacterial growth throughout the study. At $1250 \mathrm{mg} / \mathrm{L}, \mathrm{L}-\mathrm{NAC}$ demonstrated a large drop ( $4 \log _{10} \mathrm{CFU} / \mathrm{mL}$ ) in colony counts after $24 \mathrm{~h}$, whereas F-NAC did show bactericidal effect.

\section{QS molecules production and $\beta$-galactosidase activities}

In Figure 3, the production of AHL molecules of $P$. aeruginosa were confirmed by the blue-green pigmentation around the edges of the wells in LB agar. The maximum blue-green color was present by the positive control (where bacteria were incubated with no NAC). It appears that both F-NAC and L-NAC reduced AHL production, but they did not prevent the production completely. However, L-NAC reduced AHL production at sub-inhibitory concentrations that were

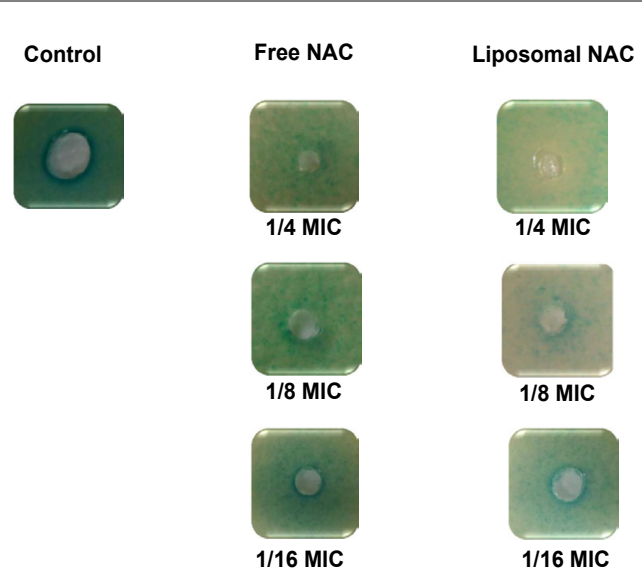

Figure 3: Sub-MICs effects on QS. The production of AHL molecules was observed after $48 \mathrm{~h}$ incubation at $30^{\circ} \mathrm{C}$ in the presence of sub-MICs $(1 / 16$ $1 / 4$ ) concentration of both free and liposomal NAC.

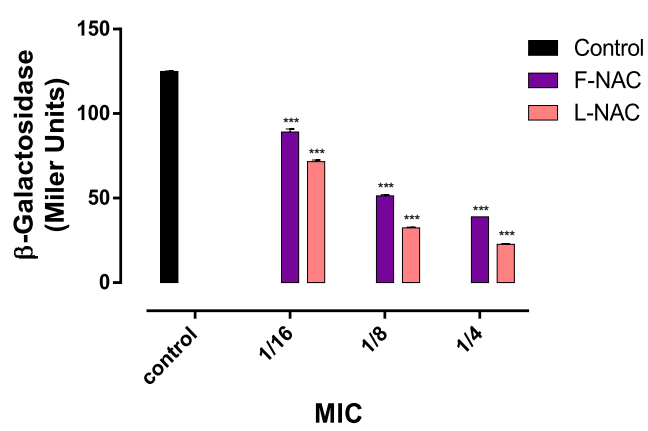

Figure 4: Sub-MICs effects on QS by $\beta$-galactosidase activity: PA-13572 samples were treated with $1 / 16,1 / 8$ and $1 / 4$ MICs of both F-NAC and L-NAC, supernatants were collected and incubated with $A$. tumefaciens (A136) and $\beta$-galactosidase activities were calculated in miller units for three independent experiments each were prepared in triplicates. These data represents the mean \pm S.E.M. for the three experiments, $P$ values were considered significant when compared to control: ${ }^{* * *} P<0.001$. 

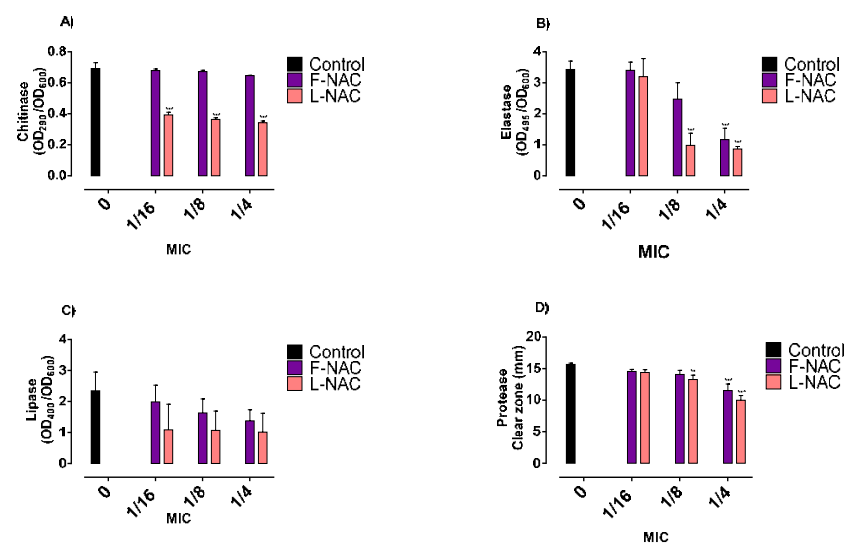

Figure 5: The production of virulence factors in the presence of L-NAC. Subinhibitory concentrations of both F-NAC \& L-NAC were added to PA13572 and incubated for $24 \mathrm{~h}$. The supernatants were tested for $(\mathbf{A})$ chitinase, (B) elastase, (C) lipase, and (D) protease. $P$ values were considered significant when compared to control ${ }^{* *} P<0.001,{ }^{* *} P<0.01$. All experiments were repeated 3 times in triplicates.

4 times lower than F-NAC. At $1 / 4$ MIC of L-NAC, the color intensity was pale blue compared to 1/4 MIC of F-NAC. At 1/8 MIC of F-NAC, the production of blue pigment ring around the edge was darker than $1 / 8$ MIC of L-NAC. The levels of $\beta$-galactosidase activity in response to AHL indicated decreasing levels of AHL signaling molecules released from $P$. aeruginosa cells exposed L-NAC compared to F-NAC (Figure 4). For example, exposing bacteria to F-NAC at $1 / 4$ MIC resulted in $38.94 \pm 0.06$ Miller unit, whereas L-NAC significantly reduced AHL signaling molecules, based on $\beta$-galactosidase activity, to $22.7 \pm 0.41$ Miller unit compared $124.9 \pm 0.34$ Miller unit resulted in control. L-NAC at $1 / 8$ MIC reduced $\beta$-galactosidase activity to $32.49 \pm 0.39$ Miller unit, whereas F-NAC only exhibited reduction of $\beta$-galactosidase activity to $51.32 \pm 0.63$ Miller unit. L-NAC was significantly more active in reducing AHL production than F-NAC at all subinhibitory concentrations $(P<0.001)$.

\section{Production of PA-13572 virulence factors in the presence of L-NAC}

The effects of F-NAC or L-NAC at $1 / 4-1 / 16$ the MIC on $P$. aeruginosa virulence factors including chitinase, elastase, lipase and protease were evaluated. F-NAC did not reduce the production of chitinase at all MICs compared to control (Figure 5A). On the other hand, L-NAC was able to reduce the level of chitinase significantly at all concentrations compared to control $(P<0.001)$, (Figure $5 \mathrm{~A})$. L-NAC was able to reduce the level of elastase significantly at $1 / 4$ MIC compared to control. Furthermore, elastase activity was reduced significantly by L-NAC at concentration eightfold lower than F-NAC $(1 / 8$ versus $1 / 4)(P<0.001)$ (Figure $5 \mathrm{~B})$. Although, F-NAC and L-NAC reduced the level of lipase, the reduction was not significant. However, L-NAC was more effective at concentration fourfold lower than the F-NAC at all subinhibitory concentrations compared to control (Figure 5C). For protease, L-NAC was able to reduce protease at a concentration fourfold lower than F-NAC (1/4 L-NAC versus 1/4 F-NAC) (Figure 5D). Furthermore, L-NAC at concentration 16-fold lower than F-NAC, exhibited a significant reduction in protease activity (1/8 L-NAC versus 1/4 F-NAC) $(P<0.01)$.

\section{Effects of L-NAC on PA-13572 motility}

We examined bacterial motility, including twitching, swimming and swarming in the presence of subinhibitory concentrations of either free or liposomal $\mathrm{N}$-acetylcysteine. F-NAC at 1/4 MIC did not reduce swarming of $P$. aeruginosa PA-13572 significantly compared to control (Figure 6A). However, L-NAC at 1/8 MIC reduced P. aeruginosa

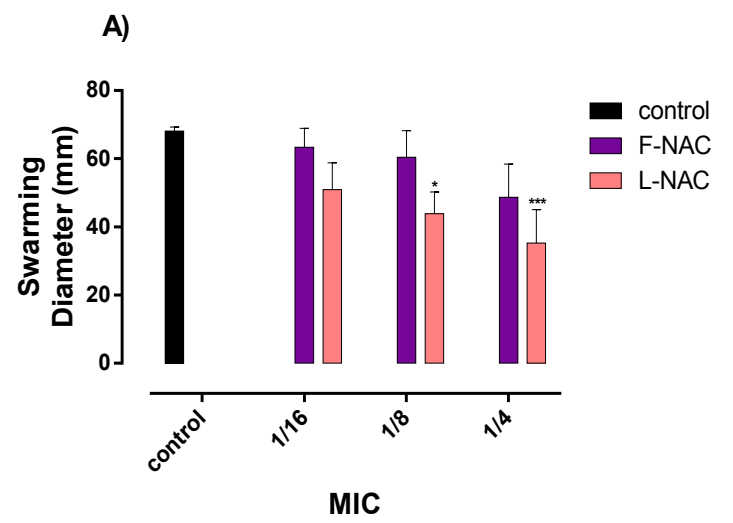

B)

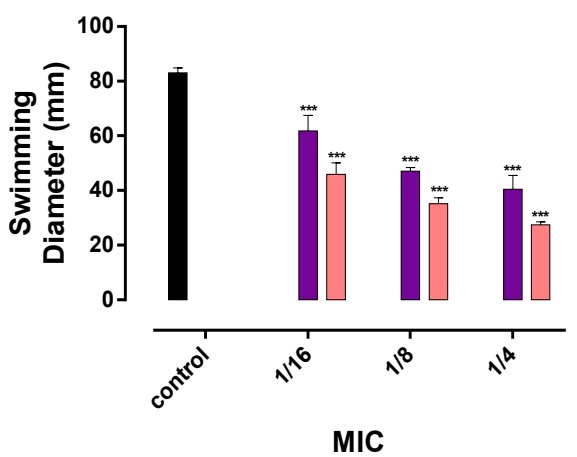

C)

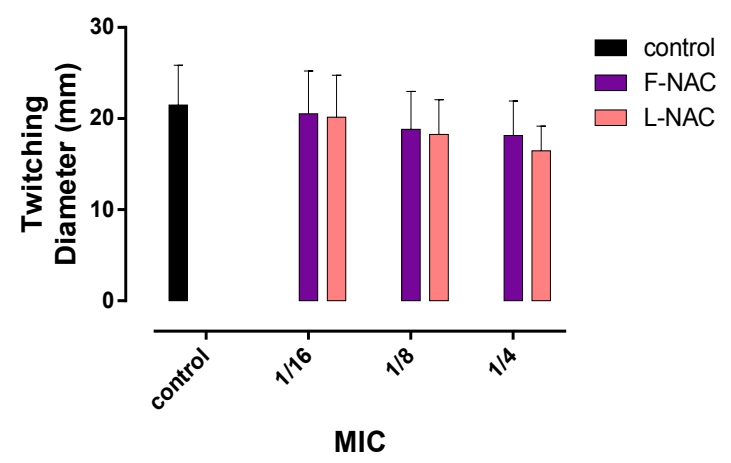

Figure 6: The effects of L-NAC on Pseudomonas aeruginosa motility. Subinhibitory concentration $(1 / 16,1 / 8$ and $1 / 4)$ of both formulations (F-NAC \& L-NAC) was added to different concentrations of agarose plates and motility was examined. (A) Swarming $(0.5 \%$ agarose w/v), (B) swimming $(0.3 \%$ agarose $w / v)$ and $($ C) twitching $(1 \%$ agarose $w / v) . P$ values were considered significant when compared to control ${ }^{* * *} P<0.001,{ }^{* *} P<0.01,{ }^{*} P<0.05$. All experiments were repeated 3 times in triplicates. 
A)

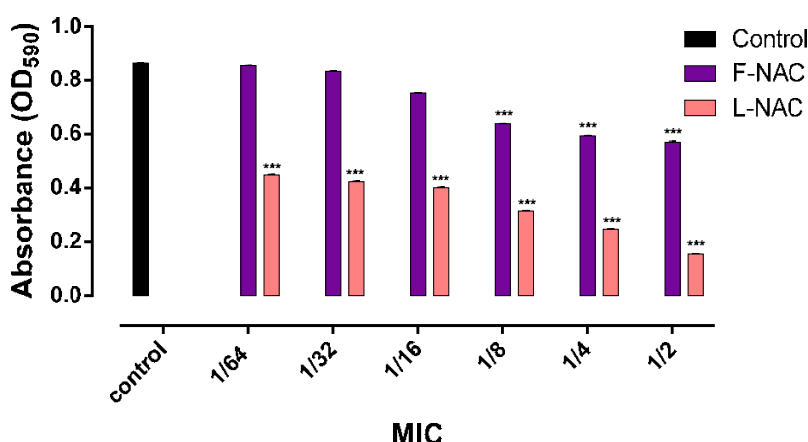

B)

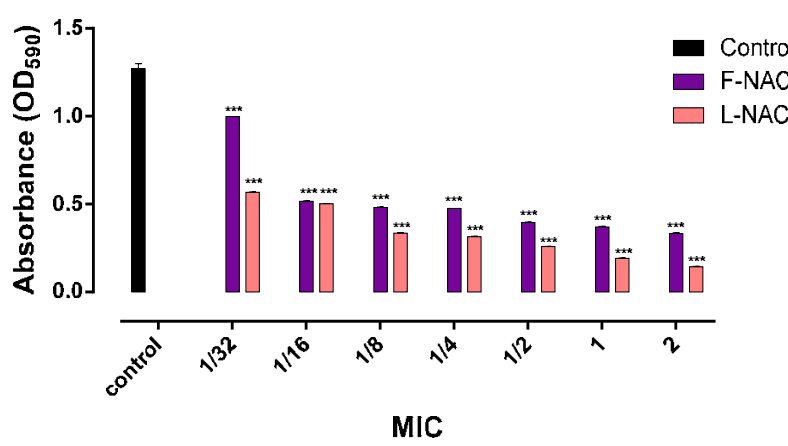

Figure 7: Prevention of biofilm formation: (A) and biofilm reduction (1-dayold biofilms) (B) in the presence of free or liposomal NAC was examined. At the prevention of biofilm formation experiment, PA-13572 were grown in 96well plates at $37^{\circ} \mathrm{C}$ for $18 \mathrm{~h}$ in the presence of different concentrations $(1 / 2$ $1 / 64$ the MIC) of both F- and L-NAC. Nonattached bacteria were washed with PBS while attached bacteria were stained with $C V$ and absorbance read at $590 \mathrm{~nm}$ was measured. For the biofilm reduction, PA-13572 were grown as above without any treatment then treated with sub-MIC or concentration above MICs F- and L- NAC then incubation for another $18 \mathrm{~h}$. Same washing and staining steps were applied and absorbance was measured as described above. All experiments were repeated three times in triplicate. $P$ values were considered significant when compared to control ${ }^{* * *} P<0.001$.

swarming significantly $(P<0.05)$ compared to control. Furthermore, the reduction of bacterial swarming was more significant at $1 / 4 \mathrm{MIC}$ of L-NAC $(P<0.001)$ (Figure 6A). On the other hand, swimming was reduced by all concentrations for both F-NAC and L-NAC compared to control (Figure 6B). However, L-NAC at concentration eightfold lower than F-NAC was able to significantly reduce swimming (1/16 L-NAC versus $1 / 8 \mathrm{~F}-\mathrm{NAC})(P<0.001)$. L-NAC at $1 / 8 \mathrm{MIC}$ also reduced the swimming pattern of $P$. aeruginosa to $35 \pm 2.2 \mathrm{~mm}$, whereas F-NAC at concentration fourfold higher than L-NAC reduced $P$. aeruginosa swimming to $40 \pm 5.2 \mathrm{~mm}$ (1/8 L-NAC versus $1 / 4 \mathrm{~F}-\mathrm{NAC})$. F-NAC and L-NAC did not affect $P$. aeruginosa twitching significantly. However, L-NAC at $1 / 4$ MIC exhibited $16.5 \pm 2.7 \mathrm{~mm}$ compared to $21.5 \pm 4.4 \mathrm{~mm}$ of control, whereas F-NAC exhibited $18.2 \pm 3.8 \mathrm{~mm}$ (Figure 6C).

\section{Anti-biofilms activities}

Polystyrene 96-well plates were used to study the prevention and reduction of $P$. aeruginosa biofilm complexes. There was no biofilm formed at the MIC, due to killing of the bacteria (data not shown) and a gradual prevention of biofilm formation no the surface was noticed when bacteria were incubated with concentration below the MIC
(1/64-1/2) of F-NAC and L-NAC. L-NAC at all tested concentrations were able to reduced attachment of biofilm onto plastic surfaces, while only three concentrations of F-NAC (1/8-1/2 MIC) were able to reduce the formation compared to control (Figure 7A). However, L-NAC was more significant in preventing formation of the biofilm. For instance, L-NAC at concentration 128-fold lower than F-NAC was able to reduce the biofilm formation significantly compared to the free formulation $(1 / 64 \mathrm{~L}-\mathrm{NAC}$ versus $1 / 2 \mathrm{~F}-\mathrm{NAC})(P<0.001)$. The reduction effects of F-NAC and L-NAC on young structured biofilms are depicted in (Figure 7B). Both formulations had a significant effect on reducing young structured biofilm; however, liposomal NAC was more significant in biofilm reduction. For example, L-NAC at concentration 16-fold lower than F-NAC (1/8 L-NAC versus $1 / 2 \mathrm{~F}-\mathrm{NAC})$ was able to reduce young biofilm structure significantly than the free formulation $(P<0.01)$. L-NAC at $1 / 4 \mathrm{MIC}$ was more significant in reducing young biofilm compared to 1 MIC of F-NAC $(P<0.01)$. The L-NAC and F-NAC activities against $P$. aeruginosa within mature biofilm community are shown in Figure 8. L-NAC was significantly better than F-NAC in reducing bacterial counts within mature biofilms compared to control and free formulation $(P<0.001)$. For instance, $\mathrm{L}-\mathrm{NAC}$ at $2500 \mathrm{mg} / \mathrm{L}$ was able to reduce bacterial community significantly compared to F-NAC at $2500 \mathrm{mg} / \mathrm{L}(P<0.001) . \mathrm{L}-\mathrm{NAC}$ at $630 \mathrm{mg} / \mathrm{L}$ was more significant in reducing bacterial counts compared to control and free formulation $(P<0.001)$.

\section{Toxicity of L-NAC}

L-NAC formulation had no toxicity effect on A549 cells. However, a slight drop of cells viability was noticed when cells were treated with $630,1250,2500$ and $5000 \mathrm{mg} / \mathrm{L}$ of F-NAC, where viability was $98 \pm$ $0.31 \%, 98 \pm 0.05 \%, 98 \pm 0.05 \%$ and $97 \pm 0.61 \%$ respectively. Cells were maintained in full viability (100\% viable) at all concentrations when treated with L-NAC (Table 2).

\section{In vitro effects of L-NAC on bacterial adhesion to human lung cells}

Treatment of bacteria with F-NAC and L-NAC prior incubation with A549: The bacterial colony counts when bacteria were treated with $2500,1250,630,310$ and $160 \mathrm{mg} / \mathrm{L}$ concentrations of both F-NAC and L-NAC are represented in Figure 9A. Bacterial adhesion to lung cells were gradually reduced as the concentrations increased, L-NAC was significantly able to reduce $P$. aeruginos $a$ adhesion at all concentrations

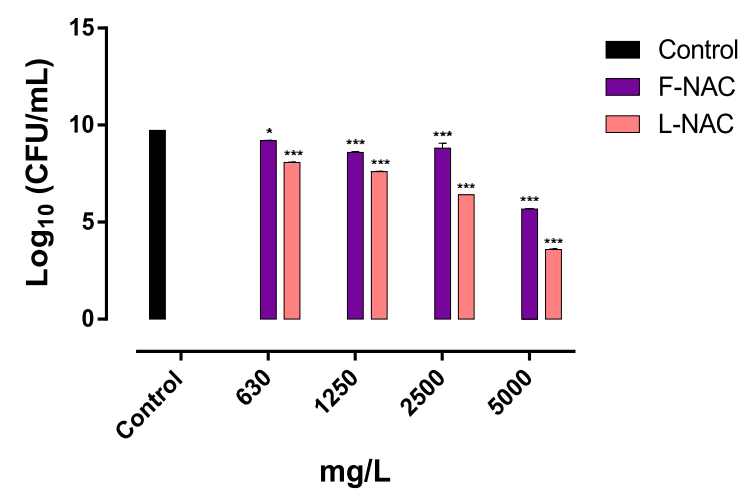

Figure 8: Liposomal NAC antibiofilm effect on PA-13572 L-NAC was able to eliminate mature biofilms (6-day-old biofilms) significantly, $P$ values were considered significant when compared to control ${ }^{* *} P<0.001,{ }^{* *} P<0.01$, ${ }^{\star} P<0.05$. All experiments were repeated 3 times in triplicates. 


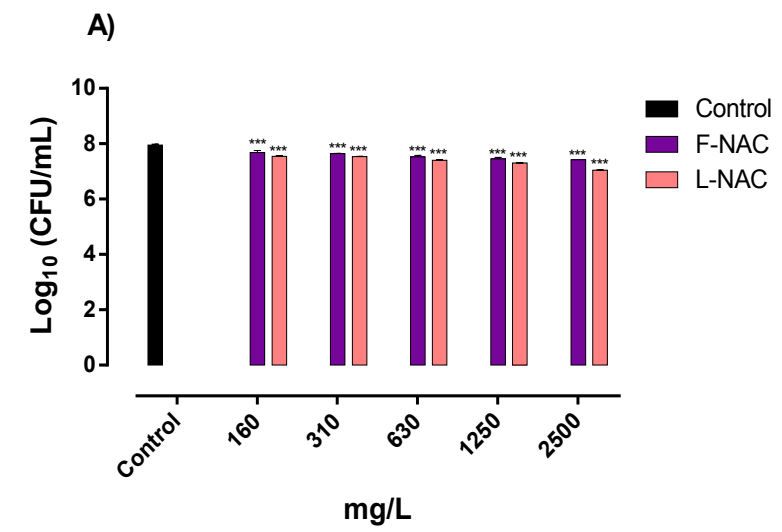

B)

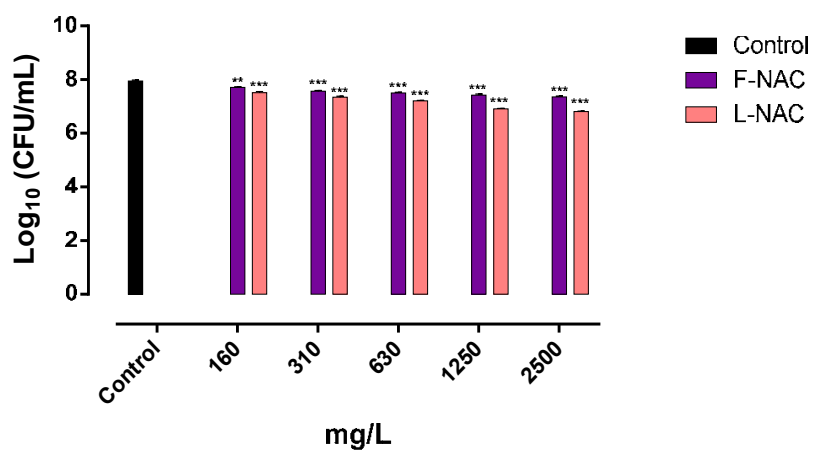

Figure 9: Bacterial adhesion to lung cells, (A) bacteria were pretreated with different concentrations of F/L-NAC, and then were added to A549 monolayers. Columns present the CFU counts when bacteria were treated. (B) A549 cells were treated with different concentrations of F/L-NAC and then bacteria were added to the cells. Columns here present the CFU counts when cells were treated. Data are the mean \pm S.E.M. of three independent studies. $P$ values were considered significant when compared to control *** $P<0.001$, ** $P<0.01$, * $P<0.05$. All experiments were repeated 3 times.

compared to control $(P<0.001)$. However, $\mathrm{L}-\mathrm{NAC}$ at $2500 \mathrm{mg} / \mathrm{L}$ was more significant in reducing bacterial adhesion to lung cells by one log compared to F-NAC at $2500 \mathrm{mg} / \mathrm{L}(P<0.001)$.

A549 treatment with F-NAC and L-NAC prior exposure to bacteria: The bacterial colony counts when lung cells were pre-treated with 2500 , 1250, 630, 310 and $160 \mathrm{mg} / \mathrm{L}$ F-NAC and L-NAC prior exposure to bacteria are represented in Figure 9B. All L-NAC concentrations were significantly effective against bacterial adhesion $(P<0.001)$ compared to control. L-NAC at the concentration of $2500 \mathrm{mg} / \mathrm{L}$ was able to reduce adhesion by more than one $\log (1.14)$ compared to the same concentration of F-NAC.

\section{Discussion}

P. aeruginosa is the most prevalent bacteria in CF; despite the use of antibiotic therapies it remains to be the most challenging bacterial infection linked to poor clinical outcomes due to the high rate of antibiotic resistance [14]. Hence, other drugs with possible antimicrobial activities are being tested for the aim of improving health status of CF patients.

NAC is one of these new promising therapies, where it has been established that NAC can enhance the efficacies of some antibiotics such as carbenicillin and ticarcillin against $P$. aeruginosa [65]. It was also reported that NAC is able to inhibit the growth of both Grampositive and Gram-negative bacteria [47], have a potential to decrease biofilm formation and reduce bacterial infection [66].

In this in vitro study we extensively tested the antimicrobial effects of L-NAC alone on the clinically isolated PA-13572. We demonstrated that liposomes were capable of enhancing NAC's antimicrobial activities against the resistant strain of $P$. aeruginosa virulence factors and biofilm. To analyze the antimicrobial activity of L-NAC against resistance $P$. aeruginosa, we initially validated their effectiveness against planktonic bacteria (Table 1). The results from the MIC and MBC experiments showed that the L-NAC was more effective than the F-NAC against more than $57 \%$ of the strains involved in this study. The MIC of F-NAC was found to be $5000 \mathrm{mg} / \mathrm{L}$ in most cases. This is in agreement with results found by Abbas et al. [23] who reported 2500-5000 mg/L for MIC values. Our L-NAC formulation was highly effective against $P$. aeruginosa strains, where MIC values for L-NAC were reduced by twofold compared to F-NAC. Our MBC values for F-NAC were between 5000 to $>10000 \mathrm{mg} / \mathrm{L}$, which are consistent to the result reported by Abd El-Aziz et al. [66] who tested P. aeruginosa isolate and found an MBC of $>8000 \mathrm{mg} / \mathrm{L}$. The MBCs for F-NAC were in a range of 2500 to $>5000 \mathrm{mg} / \mathrm{L}$, however, L-NAC were more effective in reducing the $\mathrm{MBC}$ values by twofold to fourfold compared to the free form of NAC. The different in MICs and MBCs between F-NAC and L-NAC might be due to liposomes fusion with the outer membrane of $P$. aeruginosa; which leads to higher concentration of NAC inside the bacterial cell, therefore; more effective results [67].

To confirm our present MIC and MBC findings, time kill assays were performed (Figure 2). This was also carried out to confirm the ability of L-NAC to eliminate $P$. aeruginosa growth in vitro. Even though both F-NAC and L-NAC were able to kill bacterial after only $2 \mathrm{~h}$ exposure; L-NAC killed bacteria with concentration twofold less than F-NAC ( $2500 \mathrm{mg} / \mathrm{L}$ versus $5000 \mathrm{mg} / \mathrm{L}$ ), this confirms our MBC values for both F-NAC and L-NAC. Despite that bacterial proliferation was expected for the $1 \times$ MICs for F-NAC, F-NAC exhibited a bactericidal effect at 1 $\mathrm{x}$ MIC due to the fact that MIC and MBC values for F-NAC were equal to $5000 \mathrm{mg} / \mathrm{L}$ for the bacterial strain used in this study (PA-13572). However, the L-NAC at $1250 \mathrm{mg} / \mathrm{L}$ inhibited bacterial growth after $24 \mathrm{~h}$ of incubation with $4 \mathrm{log}$ reduction in bacterial growth compared to control and $3 \log$ reduction compared to the same concentration of F-NAC. Moreover, previous study reported the bactericidal effect of F-NAC on a number of bacterial strains and showed that NAC at $80000 \mathrm{mg} / \mathrm{L}$ was bactericidal on time kill study, whereas L-NAC in our study was bactericidal at concentration 32 -fold lower than the reported concentration [37]. These antibacterial activities of NAC may be due to the fact that it acts competitively to inhibit amino acid (cysteine) utilization or, by reacting with bacterial cell proteins using the sulfhydryl group $[43,65]$.

To evaluate whether L-NAC was able to control infection, the effectiveness of L-NAC to inhibit P. aeruginosa's QS was determined. The QSI effects were investigated by monitoring the production of AHLs, which were attenuated by L-NAC at concentration four times lower than the free NAC in qualitative (Figure 3 ) and quantitative studies (Figure 4). Cugini et al. [68] have explained NAC's ability to inhibit QS in a very interesting study. They have stated that reactive oxygen species (ROS) are responsible for activating the QS pathway, thereby NAC was able to block QS pathway by suppressing hydrogen peroxide and RhIR activity (a transcriptional regulator for LasR (the master QS regulator). It was also able to stop the production of pyocyanin (one of 


\begin{tabular}{|c|c|c|c|c|}
\hline \multirow{2}{*}{ Bacterial strains } & \multicolumn{2}{|c|}{ Free N-Acetylcysteine (mg/L) } & \multicolumn{2}{|c|}{ Liposomal N-Acetylcysteine (mg/L) } \\
\hline & MIC & MBC & MIC & MBC \\
\hline PAATCC 25619 & $>10000$ & $>10000$ & $>500$ & 5000 \\
\hline PA 13572 & 5000 & 5000 & 1250 & 2500 \\
\hline PA 5 & 5000 & 5000 & 1250 & 2500 \\
\hline PA 13641-2 (M) & 5000 & 5000 & 1250 & 2500 \\
\hline PA 7 & 5000 & 10000 & 5000 & $>5000$ \\
\hline PA 13639-2 & 5000 & 10000 & 5000 & $>5000$ \\
\hline PA 3 & 5000 & 5000 & 1250 & 2500 \\
\hline PAATCC 27853 & 5000 & 10000 & 5000 & 5000 \\
\hline PA $13640(M)$ & 5000 & $>10000$ & 5000 & $>5000$ \\
\hline PA 11 & 5000 & 5000 & 1250 & 2500 \\
\hline PAATCC 10145 & 5000 & $>10000$ & 5000 & $>5000$ \\
\hline PA 12 & 5000 & 5000 & 1250 & 2500 \\
\hline PA 13639-1 (M) & 5000 & $>10000$ & 5000 & $>5000$ \\
\hline PA 48913 & 5000 & 5000 & 1250 & 2500 \\
\hline PA 26250 (M) & 5000 & 5000 & 1250 & 2500 \\
\hline PA 1 & 5000 & 5000 & 1250 & 2500 \\
\hline PA 48912-2 & 5000 & 5000 & 1250 & 2500 \\
\hline PA 48912-1 & 5000 & 10000 & 5000 & 5000 \\
\hline PA 8 & 5000 & $>10000$ & 5000 & 5000 \\
\hline PA 13641-1 & 5000 & 10000 & 5000 & 5000 \\
\hline PAO1 & 5000 & 10000 & 5000 & 5000 \\
\hline
\end{tabular}

Table 1: In vitro activities of free and liposomal NAC against $P$. aeruginosa strains.

\begin{tabular}{|c|c|c|c|}
\hline & \multicolumn{3}{|c|}{ Cell viability (\%) } \\
\hline Concentration $(\mathbf{m g} / \mathbf{L})$ & Control & Free NAC & Lipo NAC \\
\hline 0 & $100 \pm 0.00$ & $100 \pm 0.00$ & $100 \pm 0.00$ \\
\hline 160 & - & $100 \pm 0.00$ & $100 \pm 0.00$ \\
\hline 310 & - & $100 \pm 0.00$ & $100 \pm 0.00$ \\
\hline 630 & - & $98 \pm 0.31$ & $100 \pm 0.00$ \\
\hline 1250 & - & $98 \pm 0.05$ & $100 \pm 0.00$ \\
\hline 2500 & - & $98 \pm 0.02$ & $100 \pm 0.00$ \\
\hline 5000 & - & $97 \pm 0.61$ & $100 \pm 0.00$ \\
\hline
\end{tabular}

Table 2: Cell viability of epithelial lung cells exposed to free or liposomal NAC.

many toxins produced by $P$. aeruginosa that is stimulated by hydrogen peroxide). They also suggested that ROS might stimulate VF production so NAC might decrease $P$. aeruginosa virulence by decreasing the ROS level or by preventing the activation of this regulatory pathway [68]. Since the AHL production plays an important role in regulating VF [29], reduction in AHL signaling molecules results in decreasing of VF secreted by bacterial cells [69]. In this study we demonstrated that encapsulation of NAC into liposomes resulted in improving the efficacy of NAC in inhibiting VF, where L-NAC was able to reduce chitinase, elastase and protease significantly $(P<0.001)$ at sub-MICs. This support the hypothesis stated by Cugini et al. [68] that ROS stimulates the production of VF and since NAC is able to suppress the level of ROS, it was able to decrease the level of VF produced by $P$. aeruginosa.

Usually $P$. aeruginosa resist antibiotic treatment when it attaches to respiratory epithelial cells using their pili and flagella motility by forming biofilms [70]. Multiple pili generally exist on the surface of $P$. aeruginosa as small filamentous and they are responsible of rapid colonization of the airway. Flagella complex also presents on the surface of $P$. aeruginosa and play a major role in its pathogenesis where they are the main motile for Gram-negative bacteria and considered to be very immunogenic [71]. When PA-13572 was inoculated on the agar, type IV pili designated as "twitching" was not significantly inhibited (Figure 6). However, flagellum were attenuated significantly by L-NAC at $1 / 4$
MIC (compared to the same MIC of F-NAC), designated as "swarming $(P<0.01)$ and swimming $(P<0.001)$ ". Since attenuation of motility is valuable in moderating biofilm formation and bacterial adhesion to lung cells, NAC was evaluated in terms of its ability to prevent biofilm formation (biofilm attachment to plates), biofilm reduction and eradication of bacteria within mature biofilm. NAC was able to prevent $P$. aeruginosa biofilm formation at concentration as low as $1 / 64$ the MIC for both F-NAC and L-NAC (Figure 7A), both were significantly reduced compared to control; and L-NAC was significantly better than F-NAC when compared to the same group $(P<0.001)$. Concentrations above MIC were used for the aim of studying the biofilm reduction effects of L-NAC on young biofilms, where biofilms usually develop more resistance to the formulation compared to planktonic cells (Figure 7B). We demonstrated 92\% less biofilm (1-day-old PA-13572 biofilms) at 2 MICs $(2500 \mathrm{mg} / \mathrm{L})$ of L-NAC $(P<0.001)$. Our finding demonstrated higher biofilm inhibition compared to other investigator, Abd El-Aziz et al. [66] where they got $67.12 \%$ less biofilms at $2000 \mathrm{mg} / \mathrm{L}$ NAC. Mature (6-day-old) biofilms were grown on polystyrene pegs of the CBD plate to investigate eradication effects of L-NAC on more resistance form of biofilms. We have established (Figure 8) that L-NAC was able to reduce bacterial counts in mature biofilms by $46 \%$ at 2 times the MBC $(5000 \mathrm{mg} / \mathrm{L})$. Quah et al. [42] have reported that they needed 3 times the MBC of NAC to produce the maximum biofilm reduction for $E$. faecalis. The enhance delivery of NAC might be due to penetration of liposomal formulation into biofilms structure. A study reported that amikacin encapsulated in $300 \mathrm{~nm}$ liposomes consist of DPPC and cholesterol diffused more easily than $1 \mu \mathrm{m}$ liposomes through biofilms structure [72]. Liposomes used for this study was $200 \mathrm{~nm}$ in size, which offers better penetration of liposomal NAC into biofilms. Once NAC released into biofilms, it might be interfered with exopolysaccharides (EPS) production, which is considered to be one of the most important components in biofilms, by two possible ways. Either that NAC's sulfhydryl group disrupt the disulfide bonds of the bacterial enzymes responsible of EPS production, or due to NAC's antioxidant properties 
Citation: Hasanin A, Omri A (2014) Liposomal N-acetylcysteine Modulates the Pathogenesis of $P$. aeruginosa Isolated from the Lungs of Cystic Fibrosis Patient. J Nanomed Nanotechnol 5: 219. doi: 10.4172/2157-7439.1000219

which indirectly effects bacterial cell metabolism and EPS production [46,47].

To investigate the anti-adhesive capability of L-NAC, we examined the effects of this formulation on cell viability. Human lung cancer cells A549 maintain 100\% viability when exposed to all L-NAC concentrations used (Table 2). On the other hand, when exposed to F-NAC cells were less viable. This might be due to the ability of liposomes to reduce toxicity of drugs by decreasing their availability within the cell membrane; thus moderates cell toxicity [73]. Then we studied the ability of L-NAC to reduce bacterial adhesion to lung cells (A549) in vitro. L-NAC reduced bacterial adhesion to A549 monolayers significantly in dose-dependent manners compared to F-NAC (Figure 9). This support our motility experiments finding were flagella, which are responsible of $P$. aeruginosa adhesion to epithelial cells, were significantly reduced by L-NAC. We also have noticed that pretreatment of cells with L-NAC (Figure 9B) gave better protection to lung cells against bacterial adhesion compared to the results of the presence of NAC during growth of bacteria (Figure 9A). This might be due to the ability of NAC to increase the antioxidant lung cell defenses by elevating the levels of glutathione, an important antioxidant, and lowering the number of inflammatory cells $[74,75]$. We only could find few studies representing the effects of NAC on bacterial adhesion to epithelial cells; one study was by Riise et al. [76] where they have established that NAC was able to reduce adhesion of $H$. influenzae to oropharyngeal epithelial cells by $50 \%$ when bacteria were incubated with $20 \mathrm{mg} / \mathrm{mL}$. Another study represented by Zheng et al. [77] established 54\% less attachment of $M$. catarrhalis to pharyngeal epithelial cells when cells where treated with $10 \mathrm{mg} / \mathrm{mL}$ of NAC, and they found no effects on the attachment when M. catarrhalis were treated with NAC. However, we could come with agreement with both studies that NAC proved to possess antiadhesive effects.

The bacteriostatic effect of NAC is still relatively unknown; more studies on the bacterial responses to NAC may open doors to the use of this compound as an anti-biofilm agent in the future. In this study we demonstrated dramatic effects of NAC on biofilms and attachment of bacteria, this might be related to the $-\mathrm{SH}$ group which react with the bacterial proteins' disulfide bond causing irreversible damage to the bacterial proteins that are responsible for the metabolism and growth [78]. Another possibility is the ability of NAC to reduce EPS, a major component in biofilm, which leads to the changing characters of the bacterial surface and texture therefore unable $P$. aeruginosa to grow in large microcolonies [47] and to anchor to surfaces [79,80].

In conclusion, our results revealed the great antimicrobial effects of NAC on P. aeruginosa. Liposomes increase the therapeutic efficacy of NAC when encapsulated. This liposomal formulation may serve as a new strategy for the treatment of the serious problem of biofilm formation and bacterial resistance to antibiotics after conducting in vivo animal models and clinical trials to demonstrate the efficacy and safety of our formulation in patients.

\section{Acknowledgement}

This work was supported by a research grant from the Ministry of Higher Education of Kingdom of Saudi Arabia represented by Saudi Cultural Bureau in Ottawa for funding (A.H.).

\section{References}

1. Moskowitz SM, Chmiel JF, Sternen DL, Cheng E, Gibson RL, et al. (2008) Clinical practice and genetic counseling for cystic fibrosis and CFTR-related disorders. Genet Med 10: 851-868.
2. Munder A, Wölbeling F, Kerber-Momot $T$, Wedekind $D$, Baumann $U$, et al. (2011) Acute intratracheal Pseudomonas aeruginosa infection in cystic fibrosis mice is age-independent. Respir Res 12: 148.

3. Boyle MP, De Boeck K (2013) A new era in the treatment of cystic fibrosis: correction of the underlying CFTR defect. Lancet Respir Med 1: 158-163.

4. Sloane PA, Rowe SM (2010) Cystic fibrosis transmembrane conductance regulator protein repair as a therapeutic strategy in cystic fibrosis. Curr Opin Pulm Med 16: 591-597.

5. Buchanan PJ, Ernst RK, Elborn JS, Schock B (2009) Role of CFTR Pseudomonas aeruginosa and Toll-like receptors in cystic fibrosis lung inflammation. Biochem Soc Trans 37: 863-867.

6. Høiby N (2011) Recent advances in the treatment of Pseudomonas aeruginosa infections in cystic fibrosis. BMC Med 9: 32 .

7. Sheikh HS, Tiangco ND, Harrell C, Vender RL (2011) Severe hypercapnia in critically ill adult cystic fibrosis patients. J Clin Med Res 3: 209-212.

8. Döring G, Conway SP, Heijerman HG, Hodson ME, Høiby N, et al. (2000) Antibiotic therapy against Pseudomonas aeruginosa in cystic fibrosis: a European consensus. Eur Respir J 16: 749-767.

9. Pukhalsky AL, Kapranov NI, Kalashnikova EA, Shmarina GV, Shabalova LA, et al. (1999) Inflammatory markers in cystic fibrosis patients with lung Pseudomonas aeruginosa infection. Mediators Inflamm 8: 159-167.

10. Sonnenburg JL, Angenent LT, Gordon Jl (2004) Getting a grip on things: how do communities of bacterial symbionts become established in our intestine? Nat Immunol 5: 569-573.

11. Høiby N, Pressler T (2006) Emerging pathogens in cystic fibrosis. Eur Respir Mon 35: 66-78.

12. Hassett DJ, Korfhagen TR, Irvin RT, Schurr MJ, Sauer K, et al. (2010) Pseudomonas aeruginosa biofilm infections in cystic fibrosis: insights into pathogenic processes and treatment strategies. Expert Opin Ther Targets 14: 117-130.

13. O'Malley CA (2009) Infection control in cystic fibrosis: cohorting, crosscontamination, and the respiratory therapist. Respir Care 54: 641-657.

14. Gibson RL, Burns JL, Ramsey BW (2003) Pathophysiology and managemen of pulmonary infections in cystic fibrosis. Am J Respir Crit Care Med 168: 918 951

15. Kociolek MG (2009) Quorum-Sensing Inhibitors and Biofilms. Antiinfect Agents Med Chem 8: 315-326

16. Schuster M, Greenberg EP (2006) A network of networks: quorum-sensing gene regulation in Pseudomonas aeruginosa. Int J Med Microbiol 296: 73-81.

17. Deep A, Chaudhary U, Gupta V (2011) Quorum sensing and Bacterial Pathogenicity: From Molecules to Disease. J Lab Physicians 3: 4-11.

18. Yeung AT, Torfs EC, Jamshidi F, Bains M, Wiegand I, et al. (2009) Swarming of Pseudomonas aeruginosa is controlled by a broad spectrum of transcriptional regulators, including MetR. J Bacteriol 191: 5592-5602.

19. Flemming HC, Wingender $\mathrm{J}$ (2010) The biofilm matrix. Nat Rev Microbiol 8 : 623-633.

20. Hentzer M, Riedel K, Rasmussen TB, Heydorn A, Andersen JB, et al. (2002 Inhibition of quorum sensing in Pseudomonas aeruginosa biofilm bacteria by a halogenated furanone compound. Microbiology 148: 87-102.

21. Branda SS, Vik S, Friedman L, Kolter R (2005) Biofilms: the matrix revisited Trends Microbiol 13: 20-26

22. Costerton JW, Stewart PS, Greenberg EP (1999) Bacterial biofilms: a common cause of persistent infections. Science 284: 1318-1322.

23. Abbas HA, Serry FM, EL-Masry EM (2012) Combating Pseudomonas aeruginosa Biofilms by Potential Biofilm Inhibitors. Asian J Res Pharm Sci 2 : $66-72$

24. Høiby N, Krogh Johansen H, Moser C, Song Z, Ciofu O, et al. (2001) Pseudomonas aeruginosa and the in vitro and in vivo biofilm mode of growth Microbes Infect 3: 23-35

25. Høiby N (2002) New antimicrobials in the management of cystic fibrosis. Antimicrob Chemother 49: 235-238. 
Citation: Hasanin A, Omri A (2014) Liposomal N-acetylcysteine Modulates the Pathogenesis of $P$. aeruginosa Isolated from the Lungs of Cystic Fibrosis Patient. J Nanomed Nanotechnol 5: 219. doi: 10.4172/2157-7439.1000219

26. Høiby N, Ciofu O, Johansen HK, Song ZJ, Moser C, et al. (2011) The clinical impact of bacterial biofilms. Int J Oral Sci 3: 55-65.

27. Bjarnsholt T, Givskov M (2007) The role of quorum sensing in the pathogenicity of the cunning aggressor Pseudomonas aeruginosa. Anal Bioanal Chem 387: $409-414$

28. Winstanley C, Fothergill JL (2009) The role of quorum sensing in chronic cystic fibrosis Pseudomonas aeruginosa infections. FEMS Microbiol Lett 290: 1-9.

29. Alipour M, Suntres ZE, Lafrenie RM, Omri A (2010) Attenuation of Pseudomonas aeruginosa virulence factors and biofilms by co-encapsulation of bismuthethanedithiol with tobramycin in liposomes. J Antimicrob Chemother 65: 684693

30. Azghani AO, Baker JW, Shetty S, Miller EJ, Bhat GJ (2002) Pseudomonas aeruginosa elastase stimulates ERK signaling pathway and enhances IL-8 production by alveolar epithelial cells in culture. Inflamm Res 51: 506-510.

31. Frederiksen B, Koch C, Høiby N (1997) Antibiotic treatment of initial colonization with Pseudomonas aeruginosa postpones chronic infection and prevents deterioration of pulmonary function in cystic fibrosis. Pediatr Pulmonol 23: 330335

32. Davidson AG, Chilvers MA, Lillquist YP (2012) Effects of a Pseudomonas aeruginosa eradication policy in a cystic fibrosis clinic. Curr Opin Pulm Med 18: 615-621.

33. Giwercman B, Meyer C, Lambert PA, Reinert C, Høiby N (1992) High-level beta-lactamase activity in sputum samples from cystic fibrosis patients during antipseudomonal treatment. Antimicrob Agents Chemother 36: 71-76.

34. Mitchell EA, Elliott RB (1982) Controlled trial of oral $\mathrm{N}$-acetylcysteine in cystic fibrosis. Aust Paediatr J 18: 40-42.

35. Høiby N, Bjarnsholt T, Givskov M, Molin S, Ciofu O (2010) Antibiotic resistance of bacterial biofilms. Int J Antimicrob Agents 35: 322-332.

36. Brugha RE, Davies JC (2011) Pseudomonas aeruginosa in cystic fibrosis: pathogenesis and new treatments. Br J Hosp Med (Lond) 72: 614-619.

37. Aslam S , Darouiche RO (2011) Role of antibiofilm-antimicrobial agents in controlling device-related infections. Int J Artif Organs 34: 752-758.

38. Gillissen A, Nowak D (1998) Characterization of N-acetylcysteine and ambroxo in anti-oxidant therapy. Respir Med 92: 609-623.

39. Tirouvanziam R, Conrad CK, Bottiglieri T, Herzenberg LA, Moss RB, et al (2006) High-dose oral $\mathrm{N}$-acetylcysteine, a glutathione prodrug, modulates inflammation in cystic fibrosis. Proc Natl Acad Sci U S A 103: 4628-4633.

40. De Lisle RC, Roach E, Jansson K (2007) Effects of laxative and N-acetylcysteine on mucus accumulation, bacterial load, transit, and inflammation in the cystic fibrosis mouse small intestine. Am J Physiol Gastrointest Liver Physiol 293: G577-584.

41. Duijvestijn YC, Brand PL (1999) Systematic review of $\mathrm{N}$-acetylcysteine in cystic fibrosis. Acta Paediatr 88: 38-41.

42. Quah SY, Wu S, Lui JN, Sum CP, Tan KS (2012) N-acetylcysteine inhibits growth and eradicates biofilm of Enterococcus faecalis. J Endod 38: 81-85

43. Zhao T, Liu Y (2010) N-acetylcysteine inhibit biofilms produced by Pseudomonas aeruginosa. BMC Microbiol 10: 140

44. Xu JF, Qu JM, Li HP (2011) N-Acetylcysteine modulates acute lung injury induced by Pseudomonas aeruginosa in rats. Clin Exp Pharmacol Physiol 38: 345-351.

45. Marchese A, Bozzolasco M, Gualco L, Debbia EA, Schito GC, et al. (2003) Effect of fosfomycin alone and in combination with $\mathrm{N}$-acetylcysteine on $E$. coli biofilms. Int J Antimicrob Agents 22: 95-100.

46. Pérez-Giraldo C, Rodríguez-Benito A, Morán FJ, Hurtado C, Blanco MT, et al. (1997) Influence of $\mathrm{N}$-acetylcysteine on the formation of biofilm by Staphylococcus epidermidis. J Antimicrob Chemother 39: 643-646.

47. Olofsson AC, Hermansson M, Elwing H (2003) N-acetyl-L-cysteine affects growth, extracellular polysaccharide production, and bacterial biofilm formation on solid surfaces. Appl Environ Microbiol 69: 4814-4822.

48. Kelly GS (1998) Clinical applications of $\mathrm{N}$-acetylcysteine. Altern Med Rev 3 : 114-127.

49. Fan J, Shek PN, Suntres ZE, Li YH, Oreopoulos GD, et al. (2000) Liposomal antioxidants provide prolonged protection against acute respiratory distress syndrome. Surgery 128: 332-338.
50. Alipour M, Smith MG, Pucaj K, Suntres ZE (2012) Acute toxicity study of liposomal antioxidant formulations containing $\mathrm{N}$-acetylcysteine, $\alpha$-tocopherol, and $\mathrm{y}$-tocopherol in rats. J Liposome Res 22: 158-167.

51. Halwani M, Yebio B, Suntres ZE, Alipour M, Azghani AO, et al. (2008) Coencapsulation of gallium with gentamicin in liposomes enhances antimicrobial activity of gentamicin against Pseudomonas aeruginosa. J Antimicrob Chemother 62: 1291-1297.

52. Rukholm G, Mugabe C, Azghani AO, Omri A (2006) Antibacterial activity of liposomal gentamicin against $P$ seudomonas aeruginosa: a time-kill study. Int $\mathrm{J}$ Antimicrob Agents 27: 247-252.

53. Alhariri M, Azghani A, Omri A (2013) Liposomal antibiotics for the treatment of infectious diseases. Expert Opin Drug Deliv 10: 1515-1532.

54. Willis L, Hayes D Jr, Mansour HM (2012) Therapeutic liposomal dry powder inhalation aerosols for targeted lung delivery. Lung 190: 251-262.

55. Suntres ZE (2011) Liposomal Antioxidants for Protection against OxidantInduced Damage. J Toxicol 2011: 152474.

56. Alipour M, Omri A, Smith MG, Suntres ZE (2007) Prophylactic effect of liposomal $\mathrm{N}$-acetylcysteine against LPS-induced liver injuries. J Endotoxin Res 13: $297-304$

57. Alipour M, Suntres ZE, Omri A (2009) Importance of DNase and alginate lyase for enhancing free and liposome encapsulated aminoglycoside activity against Pseudomonas aeruginosa. J Antimicrob Chemother 64: 317-325.

58. Alipour M, Halwani M, Omri A, Suntres ZE (2008) Antimicrobial effectiveness of liposomal polymyxin B against resistant Gram-negative bacterial strains. Int J Pharm 355: 293-298.

59. Alipour M, Omri A, Suntres ZE (2011) Ginseng aqueous extract attenuates the production of virulence factors, stimulates twitching and adhesion, and eradicates biofilms of Pseudomonas aeruginosa. Can J Physiol Pharmacol 89: 419-427.

60. Alhariri M, Omri A (2013) Efficacy of liposomal bismuth-ethanedithiolloaded tobramycin after intratracheal administration in rats with pulmonary Pseudomonas aeruginosa infection. Antimicrob Agents Chemother 57: 569 578.

61. Zhu H Thuruthyil SJ, Willcox MD (2002) Determination of quorum-sensing signal molecules and virulence factors of Pseudomonas aeruginosa isolates from contact lens-induced microbial keratitis. J Med Microbiol 51: 1063-1070.

62. Griffith KL, Wolf RE Jr (2002) Measuring beta-galactosidase activity in bacteria: cell growth, permeabilization, and enzyme assays in 96-well arrays. Biochem Biophys Res Commun 290: 397-402.

63. Déziel E, Comeau Y, Villemur R (2001) Initiation of biofilm formation by Pseudomonas aeruginosa 57RP correlates with emergence of hyperpiliated and highly adherent phenotypic variants deficient in swimming, swarming, and twitching motilities. J Bacteriol 183: 1195-1204.

64. Halwani M, Blomme S, Suntres ZE, Alipour M, Azghani AO, et al. (2008) Liposomal bismuth-ethanedithiol formulation enhances antimicrobial activity of tobramycin. Int J Pharm 358: 278-284

65. Parry MF, Neu HC (1977) Effect of N-acetylcysteine on antibiotic activity and bacterial growth in vitro. J Clin Microbiol 5: 58-61.

66. Abd El-Aziz AA, El-Banna T, Sonbol FI, Abo-Kamar A, Seif-Eldin DW (2012) Evaluation of the combination of $\mathrm{N}$-acetylcysteine and or sodium salicylate with ciprofloxacin on bacterial adhesion and biofilm formation on urinary catheters. Int Arab J Antimicrob Agents 2.

67. Mugabe C, Halwani M, Azghani AO, Lafrenie RM, Omri A (2006) Mechanism of enhanced activity of liposome-entrapped aminoglycosides against resistant strains of Pseudomonas aeruginosa. Antimicrob Agents Chemother 50: 20162022

68. Cugini C, Morales DK, Hogan DA (2010) Candida albicans-produced farneso stimulates Pseudomonas quinolone signal production in LasR-defective Pseudomonas aeruginosa strains. Microbiology 156: 3096-3107.

69. Gospodarek E, Bogiel T, Zalas-Wiecek P (2009) Communication between microorganisms as a basis for production of virulence factors. Pol J Microbiol 58: 191-198.

70. Wozniak DJ, Keyser R (2004) Effects of subinhibitory concentrations of macrolide antibiotics on Pseudomonas aeruginosa. Chest 125: 62S-69S. 
Citation: Hasanin A, Omri A (2014) Liposomal N-acetylcysteine Modulates the Pathogenesis of $P$. aeruginosa Isolated from the Lungs of Cystic Fibrosis Patient. J Nanomed Nanotechnol 5: 219. doi: 10.4172/2157-7439.1000219

71. Kipnis E, Sawa T, Wiener-Kronish J (2006) Targeting mechanisms of Pseudomonas aeruginosa pathogenesis. Med Mal Infect 36: 78-91.

72. Meers P, Neville M, Malinin V, Scotto AW, Sardaryan G, et al. (2008) Biofilm penetration, triggered release and in vivo activity of inhaled liposomal amikacin in chronic Pseudomonas aeruginosa lung infections. J Antimicrob Chemother 61: 859-868.

73. Desjardins A, Chen T, Khalil H, Sayasith K, Lagacé J (2002) Differential behaviour of fluid liposomes toward mammalian epithelial cells and bacteria: restriction of fusion to bacteria. J Drug Target 10: 47-54.

74. Bridgeman MM, Marsden M, MacNee W, Flenley DC, Ryle AP (1991) Cysteine and glutathione concentrations in plasma and bronchoalveolar lavage fluid after treatment with $\mathrm{N}$-acetylcysteine. Thorax 46: 39-42.

75. Eklund A, Eriksson O, Håkansson L, Larsson K, Ohlsson K, et al. (1988) Oral $\mathrm{N}$-acetylcysteine reduces selected humoral markers of inflammatory cell activity in BAL fluid from healthy smokers: correlation to effects on cellular variables. Eur Respir J 1: 832-838.
76. Riise GC, Qvarfordt I, Larsson S, Eliasson V, Andersson BA (2000) Inhibitory effect of $\mathrm{N}$-acetylcysteine on adherence of Streptococcus pneumoniae and Haemophilus influenzae to human oropharyngeal epithelial cells in vitro. Respiration 67: 552-558.

77. Zheng CH, Ahmed K, Rikitomi N, Martinez G, Nagatake T (1999) The effects of $\mathrm{S}$-carboxymethylcysteine and $\mathrm{N}$-acetylcysteine on the adherence of Moraxella catarrhalis to human pharyngeal epithelial cells. Microbiol Immunol 43: 107113.

78. Sevier CS, Kaiser CA (2002) Formation and transfer of disulphide bonds in living cells. Nat Rev Mol Cell Biol 3: 836-847.

79. Huynh HQ, Couper RT, Tran CD, Moore L, Kelso R, etal. (2004) N-acetylcysteine a novel treatment for Helicobacter pylori infection. Dig Dis Sci 49: 1853-1861.

80. An YH, Friedman RJ (1998) Concise review of mechanisms of bacterial adhesion to biomaterial surfaces. J Biomed Mater Res 43: 338-348. 